\title{
The Whig Interpretation of History
}

\section{Christopher Torr}

Department of Economics, University of South Africa

\section{ABSTRACT}

In economics, as in other disciplines, one often comes across the term "whig" or its derivatives. One will find, for example, a particular account being branded as whiggish. Butterfield, who was a historian, introduced the idea of a whig interpretation of history in 1931. Since then the term has usually been used to classify an approach which views the present as the culmination of a march of progress. This paper provides a brief background to the origin of the term and why Butterfield criticised what he called the whig interpretation of history.

JEL B 49

\section{INTRODUCTION}

Nearly seventy years ago Butterfield (1931) criticised the so-called whig interpretation of history in which history is viewed as a triumphal march of progress. Butterfield pointed out that in such an approach events of the past are viewed through the eyes of the present, whereas in his opinion the correct way of writing history was to interpret the past through the eyes of the past. Since Butterfield's essay, the term "whig" and its variations have been employed in many disciplines and economics is no exception.

Today the term "whig" is often used in a critical vein. If a writer brands a particular account as "whiggish" his or her intention could very well be to criticise the approach taken. Butterfield, of course, intended the term to be worn as a badge of shame, but there are those who would prefer to wear it as a badge of honour (Samuelson, 1991). This essay will show where the term comes from and how it is used.

\section{THE WHIGS AND THE TORIES}

Butterfield borrowed the term whig from the political arena. The Whig political party was once one of the major political parties in Britain. As a political party it no longer exists, having become the Liberal Party in the second half of the 
nineteenth century. The opposing party was the Tory or Conservative party. We can place the Tories in the conservative, right wing part of the political spectrum, and the Whigs in the liberal, left wing part. As a start it may be useful to view the Whigs as those in favour of change and the Tories as those against change.

The views of the Tories and Whigs in eighteenth and nineteenth century Britain can be contrasted by considering their view on the monarchy. A Tory would tend to side with the monarchy, whereas a Whig would want the absolute power of the monarchy curtailed through parliament democracy and a bill of rights. Here the Magna Carta played an important role, as the Whigs tended to consider it as a bill of rights. Butterfield (1957: 109) notes:

Horace Walpole certainly knew what he meant when he called himself "a Whig", and indeed he was a Whig of the traditional type. In 1756 he had described how on one side of his bed hung "Magna Charta" and on the other side the warrant for Charles I's execution "on which I have written Major Charta". To be a Whig, in his view, meant to oppose the personal power of a king, and to be a Tory meant to support that power...

Although the idea later fell into disfavour, there was a time when Whigs argued that the notion of parliamentary democracy came from ancient customs. Common law, it was argued, stemmed from time immemorial. There was no need to justify common law, its success in surviving from ancient times provided its own justification. Pocock $(1987: 37)$ notes that:

The idea of the immemorial ... took on an absolute colouring ... It ceased to be a convenient fiction and was heatedly asserted as literal historical truth; and the more that came to be known about remote ages, the more vigorously it was insisted that the law was before Abraham. The common law was by definition immemorial custom.

In the Whig scheme of things, the power of the monarch was tempered by an ancient constitution:

... belief in the antiquity of the common law encouraged belief in the existence of an ancient constitution, reference to which was constantly made, precedents, maxims and principles from which were constantly alleged, and which was constantly asserted to be in some way immune from the king's prerogative action; and discussion in these terms formed one of the century's chief modes of political argument. Parliamentary debates and pamphlet controversies involving the law or the constitution 
were almost invariably carried on either wholly or partially in terms of an appeal to the past made in this way (Pocock, 1987: 46).

For the Whigs, the problem with the time immemorial argument was that it could be used against them. If a Whig could find rudiments of parliamentary procedure in the time of Edward the Confessor, a Tory could argue that Solomon provided evidence in favour of monarchical prerogative.

If the monarchy issue provided a quick litmus test as to whether someone harboured Whig or Tory views, an even quicker test was one's view of William the Conqueror. A Whig would tend to regard William as the "accursed Norman" (Colbourn, 1965: 7) who rode roughshod over the ancient liberties enjoyed by Anglo-Saxons prior to the invasion. A Tory would be inclined to view William as someone who restored stability to a dishevelled kingdom.

Although everybody agrees that William landed near Hastings in 1066, there is little agreement on the social and political conditions prior to that expedition and none on the consequences of the invasion. Douglas (1946: 16) remarks that "The posthumous career of William the Conqueror in English letters is almost as remarkable as his actual career in British history."

To take a view on William the Conqueror, you also have to take a view on the conquered. In a number of delightful sketches, Douglas shows how some historians have viewed those about to be conquered as a group of pot-bellied, gluttonous, degenerates stumbling around the Anglo-Saxon countryside in an alcoholic mist. So Hastings was a pushover, and the decadent got what they deserved.

A Whig, however, would paint William as a foreign tyrant who interrupted the glorious democracy being enjoyed by righteous rather than riotous AngloSaxons, assisted in no small measure by the discipline of an ancient constitution, which protected them from the king's prerogative. In this view society was not - prior to the invasion - arranged along feudal lines. Instead, feudalism came across the channel with the Normans, prior to which parliament had controlled the king rather than the king parliament. Fortunately for the righteous, some semblance of normality was restored when the people obtained from King John in 1215 the Magna Carta, a document which enshrined political and personal rights. Such was the picture painted by the Whigs. By now, however, it should come as no surprise to hear that attempts have been made by some historians to view the Magna Carta as a "feudal document in a feudal setting" (Butterfield, 1931: 10). 
The previous two paragraphs indicate that the issue of theory-laden facts is not an issue that is confined to the natural sciences. McMullin (1979:65) points out that "...the writing of history of science is shaped by the preconceptions that are brought to it. It is no more theory-neutral than is observation in science itself."

The discussion so far has provided a very brief background to Whig and Tory views. What, however, is the whig interpretation of history? And what do historians mean when, with faint praise, they damn a historical account as whiggish? A whig interpretation of history is not necessarily a historical account provided by somebody with Whig sympathies, although it may be. In other words you don't (or didn't) have to vote Whig in order to write a whig interpretation of history (Burrow, 1981: 2).

Butterfield illustrates the whig interpretation of history with the aid of examples drawn from the Catholic-Protestant divide. If today there is religious liberty, whom do we have to thank for this? In the whig interpretation, we have Luther to thank for setting the Reformation in motion, a movement that culminated in the religious tolerance of the twentieth century. The whig interpretation is a story of progress - progress from religious intolerance to religious tolerance. In such a story the Whigs and the Protestants are cast as the progressives and the Tories and the Catholics as the reactionaries. The whig interpretation is a story of progress told by the victors - the progressives. The past is viewed through the eyes of the present. The whig historian stands on the top of a mountain and tells the story of his ascent in terms of the conquest of lesser peaks rising cumulatively to the summit - the valleys do not feature in this abridged version. Butterfield (1931: 5) points out that a historian who adopts a whig point of view "very quickly busies himself with dividing the world into the friends and enemies of progress."

Butterfield argues that historians should attempt to understand the past in terms of the past. The movement towards religious liberty was not simply the result of progressive forces, but often the result of compromise between opposing forces. In centuries gone by, the state was on the side of the Catholic church and it was unthinkable that the church and state would allow heretics to promote unorthodox views. When those propounding unorthodox views became numerous it appeared that the only way to resolve the issue was by force. After an immense quantity of blood had been spilt, the unthinkable view started emerging that perhaps the way out was for the state to allow both sides their places in the sun. Such a view may have played no role at all in Luther's attempt to reform the church. Butterfield points out that Luther can be interpreted as a reformer who wished to cleanse the Roman Catholic church from within. 
The state now started playing the role of referee, and a good referee is a disinterested referee. The emergence of religious toleration cannot therefore only be seen as the triumph of progressive over reactionary forces. In the whig interpretation, however, we are presented with "... the workings of an obvious principle of progress, of which the Protestants and whigs have been the perennial allies while Catholics and tories have perpetually formed obstruction" (Butterfield, 1931: 12).

The Whig idea of liberty as an ancient idea was subsequently replaced by the idea that it was modern, and that constitutional innovation was required to ensure political and individual rights (Burrow, 1981: 21). In the new view, ancient Anglo-Saxons could not have enjoyed modern day liberties because the constitution had not yet developed to its modern form. The whig interpretation of history encapsulates this idea that modern is good, since history is viewed as a story of progress.

Butterfield (1944) later acknowledged that we all harbour some or other whig interpretation, and perhaps one of the chief virtues of Butterfield's original polemic was to draw attention to the fact that if we are writing whig history, we should be aware that we are so doing, and caution our readers accordingly.

\section{CONCLUSION}

Butterfield regarded the whig interpretation of history as the wrong way to go about doing history. He attempted to show that a historical reconstruction should consist of an attempt to understand the past in terms of the past. In the whig approach, the past is interpreted in terms of the present. In the process, he showed that a whig interpretation of history boils down to a story of progress told by the victorious,

It is the idea of the present as the culmination of a triumphal march of progress that is usually at issue when somebody terms a particular approach as whiggish. We end off with a couple of examples to illustrate how important it is to identify the conquered and the conquerors. Those who have conquered will obviously wish to see the present as a march of progress.

In 1991 Samuelson presented a keynote address at a History of Economics Society in Boston in which he took an unashamedly whiggish view on the development of economic theory. In his view, there is no doubt at all that economic theory has made remarkable strides this century. 
About half a century ago, Samuelson published his Foundations of Economic Analysis. Samuelson was obviously not the first economist to present economic ideas in mathematical terms, but with the benefit of hindsight (a whig device) his Foundations can be viewed as an important milestone on the road to the mathematization of economics. Those who do not agree that such mathematization is a good thing could argue that the mathematical developments over the last half-century represent a regression rather than a progression.

A further example concerns the introduction of rational expectations into economic theory. The rational expectations approach requires the model builder and the agents in the model to entertain similar expectations. Somebody who takes the view that most are by their very nature speculative, would not necessarily rejoice in the present ascendancy of the rational expectations approach. The essence of a speculative market is that the agents involved entertain different expectations and the rational expectations approach has difficulty in accommodating divergent expectations.

If you embrace the rational expectations approach and if you embrace the mathematical approach to economics, you are on the side of the victorious and it would be natural for you to believe that economics has progressed in the last fifty years. If you are languishing in the ranks of the defeated, you would not regard such recent developments as progress.

\section{REFERENCES}

1 BALTAS, A. (1994) "On the harmful effects of excessive antiWhiggism", in Trends in the historiography of science, eds K. Gavroglu, J. Christianidis and E. Nicolaidis, Dordrecht: Kluwer: 107-119.

2 BLAUG, M. (1990) "On the historiography of economics", Journal of the History of Economic Thought 12: 27-37.

3 BURROW, J.W. (1981) A liberal descent. Victorian historians and the English past, Cambridge: Cambridge University Press.

4 BUTTERFIELD, H. (1931) The whig interpretation of history, London: G. Bell and Sons.

5 BUTTERFIELD, H. (1944) The Englishman and his history, Cambridge: Cambridge University Press.

6 BUTTERFIELD, H. (1957) George III and the historians, London: Collins.

7 COLBOURN, H.T. (1965) The lamp of experience. Whig history and the intellectual origins of the American revolution, Chapel Hill: North Carolina Press. 
8 DOUGLAS, D. (1946) The Norman conquest and British historians, Glasgow: Jackson, Son \& Company.

9 McMULLIN, E. (1979) "The ambiguity of 'historicism"", in Current research in philosophy of science, eds P.D. Asquith and H.E. Kyburg, East Lansing, Michigan: Philosophy of Science Association: 55-83.

10 POCOCK, J.G.A. (1987) The ancient constitution and the feudal law. A study of English historical thought in the seventeenth century, Cambridge: Cambridge University Press.

11 SAMUELSON, P.A. (1991) "Out of the closet: A program for the whig history of economic science", Keynote address at History of Economics Society, Boston Meeting, June 20, 1987. Reprinted in The historiography of economics, ed. M. Blaug, Aldershot: Elgar: 181-190.

12 TORR, C.S.W. (1999) "Some pair-wise classifications employed in historiography". Mimeo.

13 VINCENT, J. (1995) An intelligent person's guide to history, London: Duckworth.

14 WILLIAMS, L.P. (1975) "Should philosophers be allowed to write history?" British Journal for the Philosophy of Science, 26: 241-253. 